\title{
ANALISIS EFISIENSI ENERGI, EFISIENSI EKSERGI, DAN LAJU KERUSAKAN EKSERGI PADA KOMPONEN MESIN PLTU MUARA JAWA DENGAN VARIASI PEMBEBANAN
}

\author{
Muhammad Rafianur Zulmi \\ Jurusan Teknologi Industri dan Proses, Program Studi Teknik Mesin \\ Institut Teknologi Kalimantan \\ Email: 03161048@ student.itk.ac.id \\ Doddy Suanggana \\ Jurusan Teknologi Industri dan Proses, Program Studi Teknik Mesin \\ Institut Teknologi Kalimantan \\ Email: doddy.suanggana@lecturer.itk.ac.id \\ Diniar Mungil Kurniawati \\ Jurusan Teknologi Industri dan Proses, Program Studi Teknik Mesin \\ Institut Teknologi Kalimantan \\ Email: diniarmungil@lecturer.itk.ac.id
}

\begin{abstract}
ABSTRAK
Pembangkit listrik tenaga uap atau PLTU merupakan salah satu penyuplai kebutuhan listrik yang memiliki potensi besar dalam penyediaan energi di Kalimantan Timur. PLTU Muara Jawa merupakan PLTU yang baru dibangun pada tahun 2016 dan masuk dalam sistem jaringan Mahakam pada tahun 2018. Saat ini, besarnya efisiensi dari pembangkit hanya ditentukan dengan mengacu pada efisiensi energi, metode tersebut dirasa kurang menggambarkan aspek-aspek penting dari pemanfaatan sebuah energi. Berdasarkan pemikiran tersebut, maka analisis energi dan eksergi perlu dilakukan pada unit PLTU Muara Jawa. Tujuan penelitian adalah mengkaji kondisi pembebanan terbaik pada komponen mesin PLTU Muara Jawa. Adapun variasi yang digunakan adalah variasi pembebanan dengan kapasitas 50\%; 75\%; dan 100\% dan analisis eksergi dengan variasi temperature lingkungan $25^{\circ} \mathrm{C} ; 27^{\circ} \mathrm{C}$; dan $30^{\circ} \mathrm{C}$ dengan data yang akan dianalisis adalah laju aliran massa, tekanan, temperatur, entalpi, entropi pada aliran masuk dan keluar boiler; turbin; serta kondensor yang kemudian dapat dilakukan perhitungan dan analisis data untuk mendapatkan besar efisiensi energi, efisiensi eksergi, dan laju kerusakan eksergi pada komponen mesin PLTU Muara Jawa. Hasil analisis menunjukkan bahwa pengaruh pembebanan terhadap besar efisiensi energi dan efisiensi eksergi tertinggi berada pada saat kondisi $75 \%$ daya generator dan temperatur lingkungan $30^{\circ} \mathrm{C}$.
\end{abstract}

Kata kunci: efisiensi energi, efisiensi eksergi, laju kerusakan eksergi, PLTU

\section{ABSTRACT}

Steam power plant or PLTU is one of the suppliers of electricity needs that has great potential in the supply of energy in East Kalimantan. Muara Jawa PLTU is a new PLTU that was built in 2016 and entered into the Mahakam network system in 2018. At present, the efficiency of the power plant is only determined by reference to energy efficiency, the method is considered to be less representative of the important aspects of energy utilization. Based on these thoughts, an energy and exergy analysis needs to be done at the Muara Jawa PLTU unit. The purpose of this study is to examine the best loading conditions on the engine component of Muara Jawa PLTU. The variations used are variations in loading with a capacity of 50\%; 75\%; and 100\% and exergy analysis with $25^{\circ} \mathrm{C}$ ambient temperature variations; $27^{\circ} \mathrm{C}$; and $30^{\circ} \mathrm{C}$ with the data to be analyzed are mass flow rate, pressure, temperature, enthalpy, entropy at the boiler in and out flow; turbine; and condenser which can then be calculated and analyzed data to get the energy efficiency, exergy efficiency, and 
the exergy damage rate on the engine component of Muara Jawa PLTU. The analysis showed that the effect of loading on the highest energy efficiency and the highest exergy efficiency was at the condition of $75 \%$ generator power and $30^{\circ} \mathrm{C}$ ambient temperature.

Keywords: energy efficiency, exergy efficiency, exergy desctruction rate, steam power plant

\section{PENDAHULUAN}

Energi listrik merupakan salah satu faktor utama sebagai penunjang penting perkembangan suatu daerah. Dengan semakin meningkatnya kegiatan industri dan jumlah penduduknya, kebutuhan energi listrik juga akan mengalami peningkatan. Berdasarkan Keputusan Menteri Energi dan Sumber Daya Mineral Nomor 1567k/21/MEM/2018 hingga bulan November 2017 total kapasitas pembangkit yang terpasang di Indonesia adalah 54577,9 MW yang terdiri dari pembangkit PLN 40285,7 MW, swasta 10457 MW dan sewa 3835 MW, sebagian besar pembangkit berupa Pembangkit Listrik Tenaga Uap [1]. Di Kalimantan Timur sendiri baru saja dibangun pembangkit listrik tenaga uap baru yang beroperasi sejak tahun 2016 dan masuk dalam sistem jaringan Mahakam pada tahun 2018 untuk mengetahui tingkat performa pada pembangkit perlu dilakukan pengujian performa sehingga diketahui apabila performa yang dihasilkan kurang baik.

Menurunnya performa dari kerja mesin suatu pembangkit listrik biasanya disebabkan oleh faktor adanya rugi-rugi energi yang berlebihan. Salah satu cara yang digunakan untuk mengoptimalkan sistem pembangkit adalah dengan melakukan analisis efisiensi. Namun, saat ini besarnya efisiensi dari pembangkit hanya ditentukan dengan mengacu pada efisiensi energi saja yang didasari pada Hukum I termodinamika dan metode tersebut dirasa kurang menggambarkan aspek-aspek penting dari pemanfaatan sebuah energi. Karena hal tersebut, maka perlu dilakukan kombinasi pendekatan eksergi yang didasari oleh Hukum II termodinamika untuk mengetahui ketepatan besarnya efisiensi dari suatu pembangkit. Penilaian energi juga harus berdasarkan dari kualitas maupun kuantitas sehingga kombinasi dari analisis efisiensi energi dan eksergi dapat memberikan pemahaman yang lebih optimal terhadap performa dari berbagai komponen mesin. Hilangnya energi dengan jumlah yang besar pada sebuah komponen mesin pembangkit listrik dapat terjadi di salah satu maupun lebih pada komponen mesin. Oleh karena itu, perlu dilakukan perhitungan dan analisis untuk mengetahui efisiensi dari suatu pembangkit dengan cara menganalisis efisiensi energi dan eksergi yang juga dapat digunakan untuk mengidentifikasikan jenis, penyebab, dan tempat terjadinya kerugian atau kehilangan panas pada sistem tersebut ataupun pada sub-sistem termal, sehingga perbaikan-perbaikan dan juga peningkatan kualitas dapat dilakukan.

Berdasarkan pemikiran tersebut, maka analisis efisiensi energi dan eksergi dilakukan pada unit PLTU Muara Jawa untuk dapat meningkatkan efisiensi panas dari pembangkit listrik sehingga dapat mengurangi irreversibilitas dari masing-masing komponen dalam pembangkit dan dapat menjadi acuan bagi manajemen untuk membuat skala prioritas perbaikan dan optimalisasi untuk masa yang akan mendatang dalam upaya menurunkan kerugian yang terjadi dan meningkatkan efisiensi termodinamika pada sistem PLTU Muara Jawa.

\section{METODOLOGI PENELITIAN}

Dalam proses Penelitian ini berlokasi di PLTU Muara Jawa yang dikelola oleh PT Indo Ridlatama Power yang beralamat di Teluk Dalam, Muara Jawa, Kabupaten Kutai Kartanegara, Kalimantan Timur. Analisis dilakukan menggunakan data heat balance pada PLTU Muara Jawa sebagai acuan penelitian. Analisis yang dilakukan adalah dengan menghitung keseimbangan massa dan energi pada seluruh aliran. Untuk menganalisa energi dan eksergi, diperlukan diagram alir dari PLTU Muara Jawa. Terdapat 25 titik aliran fluida yang akan dilakukan analisis, titik aliran fluida ke 1 hingga titik aliran fluida ke 25 dan dikarenakan unit yang terdapat di PLTU Muara Jawa identik maka diagram alir untuk unit 1 dan unit 2 PLTU Muara Jawa lebih jelas dapat dilihat pada Gambar 1 yang telah ditentukan nilai sifat termodinamikanya. Data laju aliran fluida didapatkan dari analisis 
keseimbangan massa, temperatur, dan tekanan dari masing-masing titik yang diperoleh pada laporan operasional pada bulan Februari 2020, sedangkan entalpi dan entropi diperoleh melalui tabel sifat termodinamika untuk air. Pengambilan data operasional PLTU Muara Jawa dilakukan agar efisiensi sistem pembangkit dapat dihitung dan dianalisis.

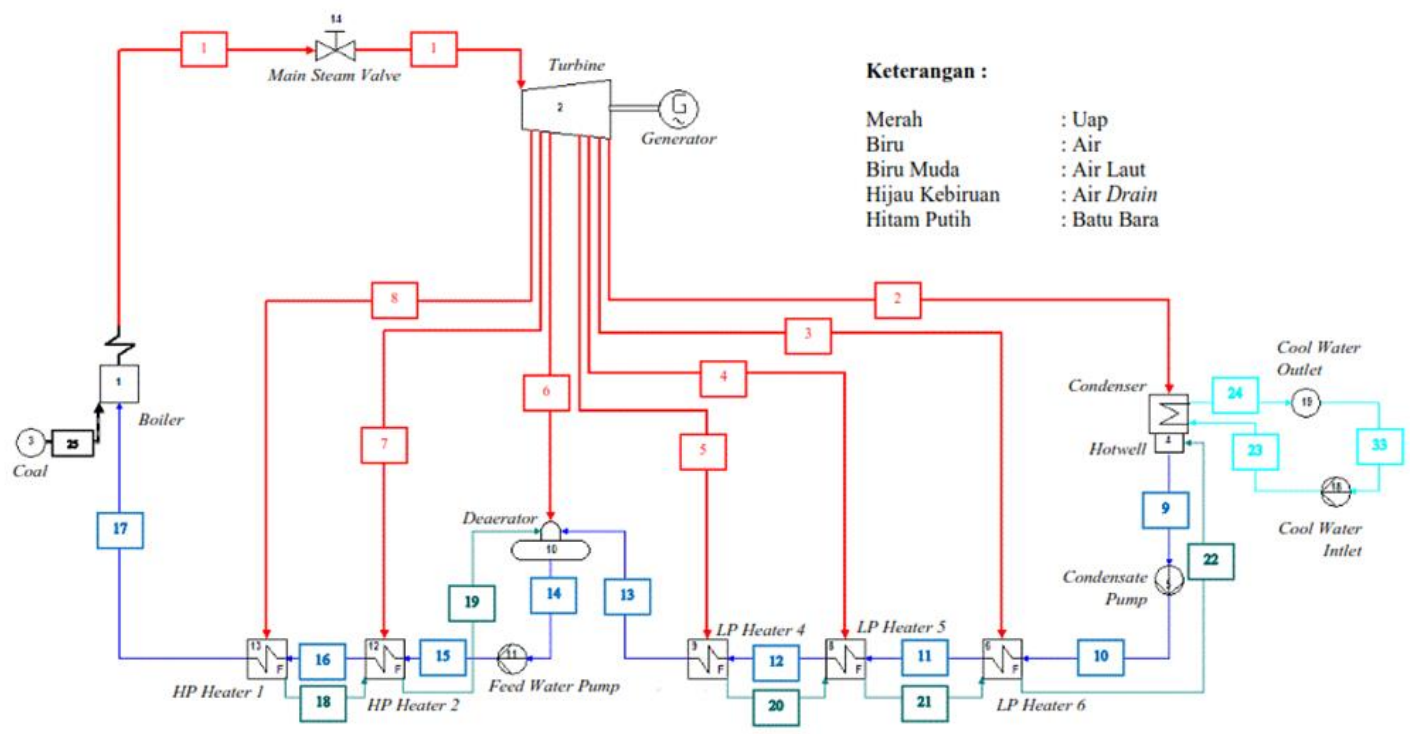

Gambar 1. Process Flow Diagram Unit 1 dan Unit 2 PLTU Muara Jawa

\subsection{ANALISIS ENERGI}

Energi adalah ukuran dari kesanggupan suatu benda untuk dapat melakukan suatu kerja. Energi berasal dari bahasa Yunani energia yang memiliki arti sebagai kemampuan untuk mengerjakan kerja. Energi merupakan besaran yang kekal, energi tidak dapat diciptakan dan tidak dapat dihancurkan, tetapi energi dapat untuk diubah dari suatu bentuk menjadi bentuk yang lain namun tidak merubah jumlah dan besar energi secara keseluruhan [2]. Analisis energi dilakukan pada efisiensi energi komponen boiler, turbin, dan kondensor yang didefinisikan pada Persamaan 1 untuk efisiensi energi boiler, Persamaan 2 untuk efisiensi energi turbin dan Persamaan 3 untuk efisiensi energi kondensor. Analisis efisiensi energi boiler ditentukan dari nilai energi pada fluida dibagi dengan energi pada bahan bakar yang dapat dihitung dengan Persamaan [3]

$$
\eta_{\text {Boiler }}=\frac{\dot{\mathrm{m}}_{1} \cdot\left(h_{1}-h_{17}\right)}{\dot{\mathrm{m}}_{\text {coal }} \cdot G C V}
$$

Keterangan:

$\begin{array}{ccl}\boldsymbol{\eta}_{\text {Boiler }} & = & \text { Efisiensi energi boiler }(\%) \\ \dot{\mathrm{m}}_{\mathbf{1}} & = & \text { Laju aliran massa fluida } 1(\mathrm{~kg} / \mathrm{s}) \\ \boldsymbol{h}_{\mathbf{1}} & = & \text { Entalpi aliran fluida } 1(\mathrm{~kJ} / \mathrm{kg}) \\ \boldsymbol{h}_{17} & = & \text { Entalpi aliran fluida } 17(\mathrm{~kJ} / \mathrm{kg}) \\ \dot{\mathrm{m}}_{\text {coal }} & = & \text { Laju aliran massa batu bara }(\mathrm{kg} / \mathrm{s}) \\ \boldsymbol{G C V} & = & \text { Gross Calorific Value }(\mathrm{kJ} / \mathrm{kg})\end{array}$

Analisis efisiensi energi turbin pada PLTU Muara Jawa ditentukan dari nilai daya yang dihasilkan turbin dibagi dengan daya bersih yang dihasilkan oleh unit yang lebih jelas dapat dilihat pada Persamaan 2 [4]

$$
\eta_{\text {turbin }}=\frac{W_{\text {turbin }}}{W_{\text {net }}}
$$

Keterangan: 


$\begin{array}{ll}\boldsymbol{\eta}_{\text {turbin }} & =\text { Efisiensi energi turbin }(\%) \\ \boldsymbol{W}_{\text {turbin }} & =\text { Daya yang dihasilkan turbin }(\mathrm{kW}) \\ \boldsymbol{W}_{\text {net }} & \begin{array}{l}\text { Daya yang dilakukan pada seluruh sistem yang merupakan } \\ \text { daya turbin yang dikurangi dengan daya pompa }(\mathrm{kW})\end{array}\end{array}$

Sedangkan analisis efisiensi energi kondensor nilainya ditentukan dari perbandingan anara energi yang masuk ke dalam kondensor dibagi dengan energi yang keluar dari kondensor yang lebih jelas dapat dilihat pada Persamaan 3

$$
\eta_{\text {kondensor }}=1-\frac{\dot{\mathrm{m}}_{9} h_{9}}{\left(\frac{\dot{\mathrm{m}}_{2} h_{2}+\dot{\mathrm{m}}_{22} h_{22}}{2}\right)}
$$

Keterangan:

$\begin{array}{cl}\boldsymbol{\eta}_{\text {kondensor }} & =\text { Efisiensi energi kondensor }(\%) \\ \dot{\mathrm{m}}_{\mathbf{9}} & =\text { Laju aliran massa fluida } 9(\mathrm{~kg} / \mathrm{s}) \\ \boldsymbol{h}_{\mathbf{9}} & =\text { Entalpi aliran fluida } 9(\mathrm{~kJ} / \mathrm{kg}) \\ \dot{\mathrm{m}}_{\mathbf{2}} & =\text { Laju aliran massa fluida } 2(\mathrm{~kg} / \mathrm{s}) \\ \boldsymbol{h}_{2} & =\text { Entalpi aliran fluida fluida } 2(\mathrm{~kJ} / \mathrm{kg}) \\ \dot{\mathrm{m}}_{22} & =\text { Laju aliran massa fluida } 22(\mathrm{~kg} / \mathrm{s}) \\ \boldsymbol{h}_{22} & =\text { Entalpi aliran fluida } 22(\mathrm{~kJ} / \mathrm{kg})\end{array}$

\subsection{ANALISIS EKSERGI}

Berbeda dengan analisis efisiensi energi analisis efisiensi eksergi menggunakan data tambahan berupa temperatur lingkungan dan tekanan lingkungan untuk dapat dilakukan analisis yang pada penelitian ini menggunakan data temperatur lingkungan $25^{\circ} \mathrm{C} ; 27^{\circ} \mathrm{C}$; dan $30^{\circ} \mathrm{C}$ dengan tekanan yang tetap sebesar 0,10074 MPa variasi temperatur pada penelitian ini dilakukan untuk mendapatkan kondisi lingkungan yang terbaik. Data entalpi dan entropi dari masing-masing temperatur lingkungan yang dianalisis lebih jelas dapat dilihat pada Tabel 1.

Tabel 1. Energi Lingkungan

\begin{tabular}{cccc}
\hline $\begin{array}{c}\text { Temperatur } \\
\text { Lingkungan } \mathbf{T}_{\mathbf{0}}\left({ }^{\mathbf{}} \mathbf{C}\right)\end{array}$ & $\begin{array}{c}\text { Tekanan Lingkungan } \mathbf{P}_{\mathbf{o}} \\
\mathbf{( M p a})\end{array}$ & Entalpi $(\mathbf{k J} / \mathbf{k g})$ & $\begin{array}{c}\text { Entropi } \\
\left(\mathbf{k J} / \mathbf{k g .}{ }^{\mathbf{}} \mathbf{C}\right)\end{array}$ \\
\hline 25 & 0,10074 & 104,92 & 0,36 \\
27 & 0,10074 & 113,28 & 0,39 \\
30 & 0,10074 & 125,86 & 0,43 \\
\hline
\end{tabular}

Data komposisi batu bara yang digunakan untuk analisis eksergi kimia bahan bakar berupa data komposisi Nitrogen; Karbon; Hidrogen; Sulfur; dan Oksigen yang diperoleh dari hasil analisis batu bara yang digunakan. Persamaan Stoikiometri digunakan untuk didapatkan rumus kimia dari batu bara yang digunakan lebih jelas dapat dilihat pada Tabel 2.

Tabel 2. Komposisi Batubara

\begin{tabular}{ccccc}
\hline Komposisi & Persentase (\%) & Massa Molar & mol/1000g & $\begin{array}{c}\text { mol/mol } \\
\text { karbon }\end{array}$ \\
\hline C & 43,44 & 12 & 36,2 & 1 \\
H & 3,13 & 1 & 31,3 & 0,86 \\
O & 13,46 & 16 & 8,41 & 0,22 \\
N & 0,9 & 14 & 0,64 & 0,01 \\
S & 0,17 & 32 & 0,05 & 0,001 \\
\hline
\end{tabular}

Tabel 2 merupakan tabel komposisi dari batu bara dan perhitungan dengan menggunakan Persamaan Stoikiometri sehingga dapat diketahui rumus kimia molekul batu bara yang digunakan 
adalah $\mathrm{CH}_{0,86} \mathrm{O}_{0,22} \mathrm{~N}_{0,01} \mathrm{~S}_{0,001}$. Pada analisis eksergi nilai dari total eksergi dari suatu sistem dapat dibagi menjadi empat komponen yaitu antara lain [5]

$$
E_{x}^{\mathrm{Tot}}=E_{x}^{P H}+E_{x}^{K N}+E_{x}^{P T}+E_{x}^{C H}
$$

Keterangan:

$$
\begin{array}{ll}
\boldsymbol{E}_{\boldsymbol{x}}^{\text {Tot }} & =\text { Eksergi total }(\mathrm{kW}) \\
\boldsymbol{E}_{\boldsymbol{x}}^{\boldsymbol{P H}} & =\text { Eksergi fisik }(\mathrm{kW}) \\
\boldsymbol{E}_{\boldsymbol{x}}^{\boldsymbol{K N}} & =\text { Eksergi kinetik }(\mathrm{kW}) \\
\boldsymbol{E}_{\boldsymbol{x}}^{\boldsymbol{P T}} & =\text { Eksergi potensial }(\mathrm{kW}) \\
\boldsymbol{E}_{\boldsymbol{x}}^{\boldsymbol{C H}} & =\text { Eksergi kimia }(\mathrm{kW})
\end{array}
$$

Eksergi yang dianalisis pada PLTU Muara Jawa akan mengabaikan eksergi potensial dan eksergi kinetik karena sistem yang diam relatif terhadap lingkungan sehingga total eksergi pada aliran hanya akan terdiri dari dua komponen utama yaitu eksergi fisik dan eksergi kimia sebagai berikut [5]

$$
E_{x}^{\text {Tot }}=E_{x}^{P H}+E_{x}^{C H}
$$

Keterangan:

$$
\begin{array}{ll}
\boldsymbol{E}_{\boldsymbol{x}}^{\text {Tot }} & =\text { Eksergi total }(\mathrm{kW}) \\
\boldsymbol{E}_{\boldsymbol{x}}^{\boldsymbol{P H}} & =\text { Eksergi fisik }(\mathrm{kW}) \\
\boldsymbol{E}_{\boldsymbol{x}}^{\boldsymbol{C H}} & =\text { Eksergi kimia }(\mathrm{kW})
\end{array}
$$

Eksergi fisik merupakan eksergi yang ditentukan dari perubahan tekanan dan temperatur dalam aliran, dengan eksergi fisik dalam sebuah sistem tertutup pada keadaan tertentu dapat dihitung dengan Persamaan [5]

$$
E_{x}^{P H}=\dot{\mathrm{m}}\left[\left(h-h_{0}\right)-T_{0}\left(S-S_{0}\right)\right]
$$

Keterangan:

$$
\begin{array}{cl}
\boldsymbol{E}_{\boldsymbol{x}}^{\boldsymbol{P H}} & =\text { Eksergi fisik }(\mathrm{kW}) \\
\dot{\mathrm{m}} & =\text { Laju fluida }(\mathrm{kg} / \mathrm{s}) \\
\boldsymbol{h} & =\text { Entalpi fluida }(\mathrm{kJ} / \mathrm{kg}) \\
\boldsymbol{h}_{\mathbf{0}} & =\text { Entalpi lingkungan }(\mathrm{kJ} / \mathrm{kg}) \\
\boldsymbol{T}_{\mathbf{0}} & =\text { Temperatur lingkungan }\left({ }^{\circ} \mathrm{C}\right) \\
\boldsymbol{S} & =\text { Entropi fluida }\left(\mathrm{kJ} / \mathrm{kg} .{ }^{\circ} \mathrm{C}\right) \\
\boldsymbol{S}_{\mathbf{0}} & =\text { Entropi lingkungan }\left(\mathrm{kJ} / \mathrm{kg} .{ }^{\circ} \mathrm{C}\right)
\end{array}
$$

Sedangkan eksergi kimia merupakan eksergi yang ditentukan dengan perubahan senyawa kimia yang dapat dihitung dengan Persamaan [5]

$$
E_{x}^{C H}=\dot{\mathrm{m}} \cdot e_{x}^{C H}
$$

Keterangan:

$$
\begin{array}{cl}
\boldsymbol{E}_{\boldsymbol{x}}^{\boldsymbol{C H}} & =\text { Eksergi kimia }(\mathrm{kW}) \\
\dot{\mathrm{m}} & =\text { Laju fluida }(\mathrm{kg} / \mathrm{s}) \\
\boldsymbol{e}_{\boldsymbol{x}}^{\boldsymbol{C H}} & =\text { Eksergi molar }(\mathrm{kJ} / \mathrm{kmol})
\end{array}
$$

Dengan nilai eksergi molar dapat dihitung dengan menggunakan Persamaan [6]

$$
e_{x}^{C H}=\frac{e_{x}^{-C H}}{M}
$$

Keterangan:

$$
\begin{aligned}
& \boldsymbol{e}_{x}^{\boldsymbol{C H}} \quad=\text { Eksergi molar }(\mathrm{kJ} / \mathrm{kmol}) \\
& \boldsymbol{e}_{\boldsymbol{x}}^{-\boldsymbol{C H} \boldsymbol{H}} \quad=\text { Eksergi molar standar }(\mathrm{kJ} / \mathrm{kmol}) \\
& \boldsymbol{M} \quad=\text { Massa molekul relatif }(\mathrm{kg} / \mathrm{kmol})
\end{aligned}
$$

Dengan nilai eksergi molar standar didapatkan dari table $\mathrm{C} 1$ dan $\mathrm{C} 2$ pada buku Thermal Design and Optimization [7]. Nilai eksergi kimia bahan bakar ditentukan dengan menggunakan Persamaan

$$
E_{x \text { Fuel }}^{\text {CH }}=\beta . G C V
$$

Keterangan:

$$
\boldsymbol{E}_{\boldsymbol{x}_{\text {Fuel }}}^{\text {CH }} \quad=\text { Eksergi kimia bahan bakar }(\mathrm{kW})
$$




$$
\begin{array}{lll}
\boldsymbol{\beta} & = & \text { Rasio eksergi } \\
\boldsymbol{G C V} & = & \text { Gross Calorific Value }(\mathrm{kJ} / \mathrm{kg})
\end{array}
$$

Nilai rasio eksergi dari bahan bakar hidrokarbon $\beta$ terhadap nilai dari GCV bahan bakar [8] dapat dihitung dengan Persamaan

$$
\beta=1,0437+0,1882\left(\frac{H}{C}\right)+0,0610\left(\frac{O}{C}\right)+0,0404\left(\frac{N}{C}\right)
$$

Keterangan:

$$
\begin{array}{ll}
\boldsymbol{\beta} & =\text { Rasio eksergi } \\
\boldsymbol{H} & =\text { Fraksi massa hidrogen } \\
\boldsymbol{C} & =\text { Fraksi massa karbon } \\
\boldsymbol{O} & =\text { Fraksi massa oksigen } \\
\boldsymbol{N} & =\text { Fraksi massa nitrogen }
\end{array}
$$

Namun Persamaan 10 hanya berlaku apabila rasio massa oksigen terhadap karbon kurang dari 0,667 [8]. Nilai eksergi yang hilang pada suatu 6ystem komponen mesin dapat dicari dengan mencari selisih antara eksergi yang masuk dengan eksergi yang keluar yang dapat dihitung dengan Persamaan [5]

$$
E_{x D}=E_{x i n}-E_{x o u t}
$$

Keterangan:

$$
\begin{array}{ll}
\boldsymbol{E}_{\boldsymbol{x} \boldsymbol{D}} & =\text { Eksergi yang hilang }(\mathrm{kW}) \\
\boldsymbol{E}_{\text {xin }} & =\text { Eksergi fluida yang masuk }(\mathrm{kW}) \\
\boldsymbol{E}_{\text {xout }} & =\text { Eksergi fluida yang keluar }(\mathrm{kW})
\end{array}
$$

Setelah didapatkan nilai eksergi pada masing-masing aliran, kemudian dapat dilakukan perhitungan analisis efisiensi eksergi boiler yang didapatkan dengan perbandingan antara laju kerusakan eksergi yang terjadi di boiler dan total eksergi yang terjadi di boiler atau dapat dirumuskan dengan Persamaan [9]

$$
\eta_{I I, \text { Boiler }}=1-\left(\frac{\dot{\mathrm{I}}_{\text {Boiler }}}{\dot{\mathrm{E}}_{x_{\text {Boilerin }}}+\dot{\mathrm{E}}_{x \text { Boilerout }}}\right)
$$

Keterangan:

$$
\begin{aligned}
\boldsymbol{\eta}_{\text {II,Boiler }} & =\text { Efisiensi eksergi boiler }(\%) \\
\dot{\mathrm{I}}_{\text {Boiler }} & =\text { Laju kerusakan eksergi boiler }(\mathrm{kW}) \\
\dot{\mathrm{E}}_{\boldsymbol{x}_{\text {Boilerin }}} & =\text { Eksergi yang masuk boiler }(\mathrm{kW}) \\
\dot{\mathrm{E}}_{\text {xBoilerout }} & =\text { Eksergi yang keluar boiler }(\mathrm{kW})
\end{aligned}
$$

Dengan nilai dari laju kerusakan eksergi pada boiler didapatkan menggunakan persamaaan [9]

$$
\dot{\mathrm{E}}_{x_{\text {Boiler In }}}=\dot{\mathrm{E}}_{x \text { Boiler out }}+\dot{\mathrm{I}}_{\text {Boiler }}
$$

Keterangan:

$$
\begin{array}{ll}
\dot{\mathrm{I}}_{\text {Boiler }} & =\text { Laju kerusakan eksergi boiler }(\mathrm{kW}) \\
\dot{\mathrm{E}}_{\boldsymbol{x}_{\text {Boilerin }}} & =\text { Eksergi yang masuk boiler }(\mathrm{kW}) \\
\dot{\mathrm{E}}_{\boldsymbol{x} \text { Boilerout }} & =\text { Eksergi yang keluar boiler }(\mathrm{kW})
\end{array}
$$

Perhitungan analisis efisiensi eksergi turbin didapatkan dengan perbandingan antara laju kerusakan eksergi yang terjadi di turbin dan total eksergi yang terjadi di turbin atau dapat dirumuskan dengan Persamaan [9]

$$
\eta_{I I, S T}=1-\left(\frac{\dot{\mathrm{I}}_{S T}}{\dot{\mathrm{E}}_{x_{\text {STin }}}+\dot{\mathrm{E}}_{\text {xSTout }}}\right)
$$

Keterangan:

$\begin{aligned} \boldsymbol{\eta}_{\boldsymbol{I I}, \boldsymbol{S T}} & =\text { Efisiensi eksergi turbin }(\%) \\ \dot{\mathrm{I}}_{\text {ST }} & =\text { Laju kerusakan eksergi turbin }(\mathrm{kW}) \\ \dot{\mathrm{E}}_{\boldsymbol{x} \text { STin }} & =\text { Eksergi yang masuk turbin }(\mathrm{kW}) \\ \dot{\mathrm{E}}_{\boldsymbol{x} \text { STout }} & =\text { Eksergi yang keluar turbin }(\mathrm{kW})\end{aligned}$


Dengan nilai dari laju kerusakan eksergi turbin didapatkan menggunakan persamaaan [9]

$$
\dot{\mathrm{E}}_{x_{\text {STin }}}=\dot{\mathrm{E}}_{x \text { STout }}+\dot{\mathrm{I}}_{S T}+W_{\text {turbin }}
$$

Keterangan:

$$
\begin{aligned}
\dot{\mathrm{I}}_{\text {ST }} & =\text { Laju kerusakan eksergi turbin }(\mathrm{kW}) \\
\dot{\mathrm{E}}_{\boldsymbol{x}} & =\text { Eksergi yang masuk turbin }(\mathrm{kW}) \\
\dot{\mathrm{E}}_{\boldsymbol{x} \text { STout }} & =\text { Eksergi yang keluar turbin }(\mathrm{kW}) \\
\boldsymbol{W}_{\text {turbin }} & =\text { Daya yang dihasilkan turbin }(\mathrm{kW})
\end{aligned}
$$

Sedangkan perhitungan analisis efisiensi eksergi kondensor didapatkan dengan perbandingan antara eksergi yang keluar kondensor dengan eksergi masuk kondensor atau dapat dirumuskan dengan Persamaan [9]

$$
\eta_{I I, \text { kondensor }}=1-\left(\frac{\dot{\mathrm{E}}_{\text {xkondensor out }}}{\dot{\mathrm{E}}_{x_{\text {kondensorin }}}}\right)
$$

Keterangan:

$$
\begin{aligned}
\boldsymbol{\eta}_{\boldsymbol{I I} \text {,kondensor }} & =\text { Efisiensi eksergi kondensor }(\%) \\
\dot{\mathrm{E}}_{\boldsymbol{x} \text { kondensorin }} & =\text { Eksergi yang masuk kondensor }(\mathrm{kW}) \\
\dot{\mathrm{E}}_{\text {xkondensor out }} & =\text { Eksergi yang keluar kondensor }(\mathrm{kW})
\end{aligned}
$$

Dengan nilai dari laju kerusakan eksergi kondensor didapatkan menggunakan Persamaan [9]

$$
\dot{\mathrm{E}}_{x_{\text {kondensor In }}}=\dot{\mathrm{E}}_{x \text { kondensor Out }}+\dot{\mathrm{I}}_{\text {kondensor }}
$$

Keterangan:

$$
\begin{array}{ll}
\dot{\mathrm{I}}_{\text {kondensor }} & =\text { Laju kerusakan eksergi kondensor }(\mathrm{kW}) \\
\mathrm{E}_{\boldsymbol{x}_{\text {kondensor In }}} & =\text { Eksergi yang masuk kondensor }(\mathrm{kW}) \\
\dot{\mathrm{E}}_{\boldsymbol{x} \text { kondensor } \text { out }} & =\text { Eksergi yang keluar kondensor }(\mathrm{kW})
\end{array}
$$

\section{HASIL PENELITIAN DAN PEMBAHASAN}

\subsection{HASIL ANALISIS EFISIENSI ENERGI}

Hasil analisis perhitungan efisiensi energi pada Unit 1 dan Unit 2 PLTU Muara Jawa yang dilakukan analisis pada masing-masing komponen mesin. Analisis dilakukan pada efisiensi energi boiler, turbin, dan kondensor. Pada Gambar 2 menunjukkan hasil analisis pada boiler mengalami perbedaan nilai pada setiap kondisi pembebanan, untuk unit 1 mengalami efisiensi energi boiler terendah pada kondisi pembebanan 50\% dan efisiensi energi boiler tertinggi terjadi pada kondisi pembebanan $100 \%$, sedangkan pada unit 2 mengalami efisiensi boiler terendah pada kondisi pembebanan $100 \%$ dan efisiensi energi boiler tertinggi pada kondisi pembebanan $75 \%$. Nilai efisiensi boiler yang terjadi pada unit 2 sangat merugikan pembangkit karena pada kondisi pembebanan $100 \%$ boiler mengalami efisiensi energi terendah, hal ini disebabkan karena adanya gangguan pada boiler yang kurang diperhatikan serta energi yang keluar boiler yang tidak sebesar dibandingkan pada boiler unit 1. Hasil analisis efisiensi energi turbin pada unit 1 dan unit 2 mendapatkan nilai tertinggi pada kondisi pembebanan $75 \%$ hal ini disebabkan karena pada kondisi pembebanan $75 \%$ energi uap yang masuk ke dalam turbin mendapatkan nilai tertinggi dibandingkan kondisi lain hal ini didasari pada temperatur uap masuk turbin yang tinggi pada kondisi pembebanan 75\%. Hasil analisis efisiensi energi kondensor pada unit 1 terjadi pada kondisi $75 \%$ hal ini disebabkan karena energi yang masuk maupun energi yang keluar dari kondensor terdapat selisih perbandingan yang tinggi yang ditunjukkan dari beberapa faktor yang mempengaruhi seperti tekanan vakum pada kondensor maupun kebersihan dari kondensor. Namun pada hasil analisis efisiensi energi unit 2 untuk komponen mesin kondensor didapati bahwa efisiensi energi relatif sama dan tidak terjadi selisih efisiensi energi yang signifikan hal ini disebabkan karena tingkat energi masuk maupun keluar dari kondensor unit 2 yang relatif stabil. Hal ini menunjukkan bahwa kerja dari kondensor unit 2 dalam kondisi yang sangat baik pada setiap penambahan pembebanan. 


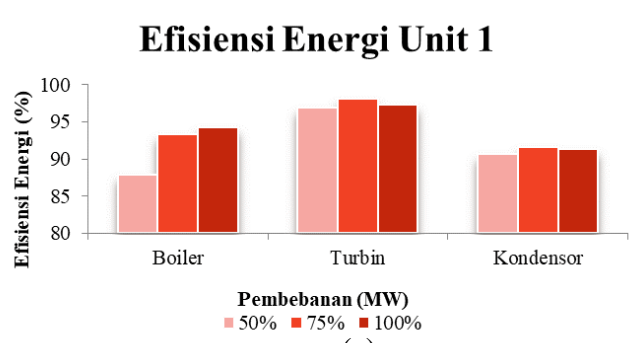

(a)

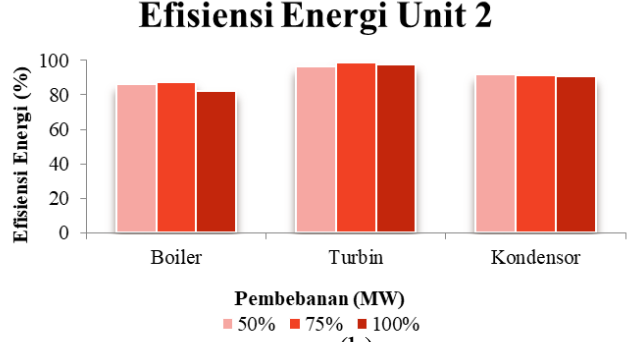

(b)

Gambar 2. Hasil Analisis Efisiensi Energi (a) Unit 1 dan (b) Unit 2

\subsection{HASIL ANALISIS LAJU KERUSAKAN EKSERGI}

Pada 25 titik aliran yang dilakukan analisis terdapat dua jenis eksergi, yaitu eksergi fisik dan eksergi kimia, dengan eksergi fisik merupakan nilai eksergi yang diperoleh dari sifat termodinamika sedangkan eksergi kimia merupakan nilai eksergi yang diperoleh dari molaritas aliran.

Setelah besar eksergi fisik dan kimia pada seluruh aliran telah ditentukan maka kedua eksergi tersebut dijumlahkan sehingga mendapatkan nilai dari total eksergi pada aliran. Kemudian besar laju kerusakan eksergi pada masing-masing komponen mesin diperoleh dari selisih antara besar nilai eksergi masuk dengan besar nilai eksergi keluar. Aliran masuk dan keluar dari sistem dapat dilihat pada Gambar 1 untuk process flow diagram di PLTU Muara Jawa. Sehingga didapatkan besar nilai kerusakan eksergi pada unit 1 dan unit 2 PLTU Muara Jawa yang lebih jelas yang dapat dilihat pada Gambar 3 dan Gambar 4.

\section{Laju Kerusakan Eksergi Unit 1}

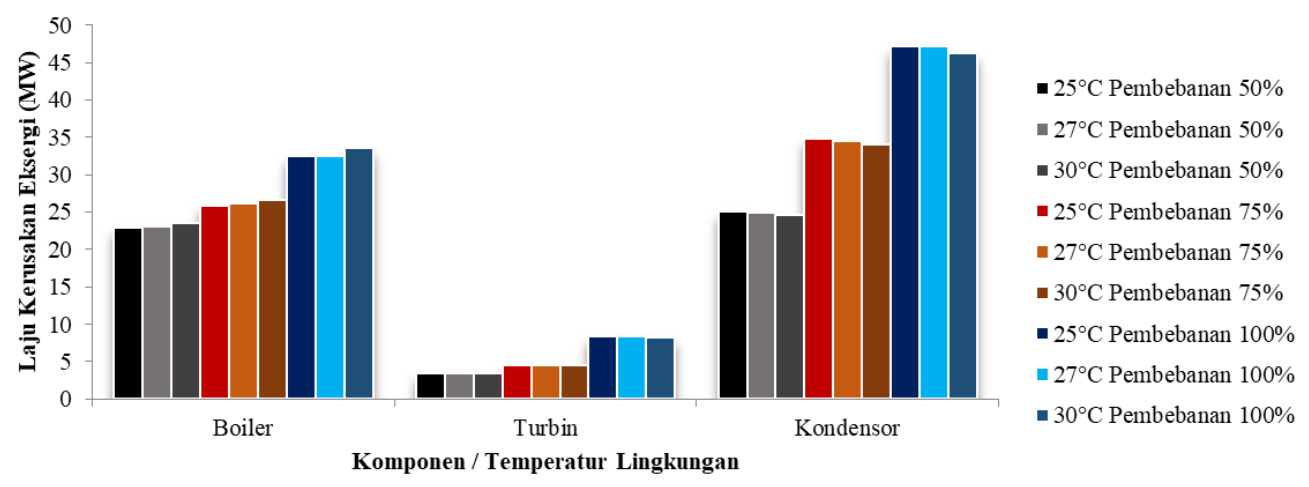

Gambar 3. Hasil Analisis Laju Kerusakan Eksergi Unit 1 pada Temperatur Lingkungan $25^{\circ} \mathrm{C}$; $27^{\circ} \mathrm{C}$; dan $30^{\circ} \mathrm{C}$ 


\section{Laju Kerusakan Eksergi Unit 2}

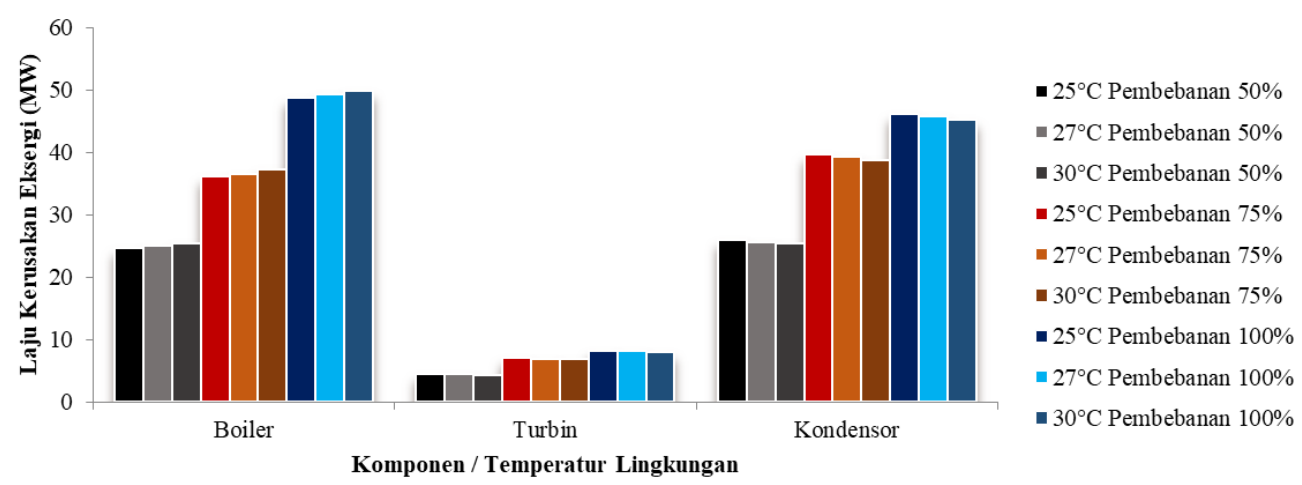

Gambar 4. Hasil Analisis Laju Kerusakan Eksergi Unit 2 pada Temperatur Lingkungan $25^{\circ} \mathrm{C}$; $27^{\circ} \mathrm{C}$; dan $30^{\circ} \mathrm{C}$

Gambar 3 dan Gambar 4 diketahui bahwa laju kerusakan eksergi pada setiap penambahan temperatur lingkungan relatif mengalami peningkatan dan sangat signifikan pada setiap penambahan tingkat beban daya generator terutama pada boiler, hal ini disebabkan karena energi dari luar lingkungan yang turut membantu kerja dari boiler ini merupakan hal yang baik sehingga energi uap yang masuk ke dalam turbin akan meningkat yang membuat kerja dari boiler akan berkurang. Meningkatnya laju kerusakan eksergi juga disebabkan karena semakin besar nilai selisih antara perubahan entropi sistem dengan perubahan entropi lingkungan, maka akan semakin besar tingkat irreversibilitas. Namun demikian, laju kerusakan eksergi pada setiap penambahan temperatur lingkungan relatif menurun walaupun tetap terjadi peningkatan pada setiap penambahan beban daya generator pada komponen mesin turbin, hal ini disebabkan karena meningkatnya energi yang masuk ke dalam turbin sehingga menyebabkan nilai perubahan entropi pada sistem dengan nilai perubahan entropi lingkungan semakin kecil. Nilai laju kerusakan eksergi pada komponen mesin kondensor mengalami peningkatan pada setiap penambahan temperatur lingkungan dan sangat signifikan pada setiap penambahan tingkat beban daya generator. Meningkatnya laju kerusakan eksergi pada kondensor disebabkan karena semakin besar nilai selisih antara perubahan entropi sistem dengan perubahan entropi lingkungan, maka akan semakin besar tingkat irreversibilitas.

Laju kerusakan eksergi pada komponen utama diakibatkan oleh tiga faktor irreversibilitas yaitu pada reaksi pembakaran, gesekan, dan perpindahan kalor. Ketiga faktor tersebut terjadi pada ruang pembakaran dengan reaksi kimia menjadi sumber laju kerusakan eksergi yang sangat signifikan yang juga berhubungan dengan perpindahan kalor, sedangkan pada turbin laju kerusakan eksergi diakibatkan oleh gesekan, dan kondensor laju kerusakan eksergi diakibatkan oleh perpindahan kalor, dan gesekan.

Laju kerusakan eksergi tertinggi terjadi di boiler yang pada hakekatnya proses pembakaran didalam boiler merupakan sumber irreversibilitas yang sangat signifikan terhadap laju kerusakan eksergi. Dengan demikian, untuk mengurangi hal tersebut, perlu dilakukan pengecekan secara rutin pada sistem boiler serta perawatan berkala. Hal ini juga perlu dilakukan pada komponen utama lainnya agar tidak menyebabkan laju kerusakan eksergi yang menjadi besar, sebagaimana yang diamati di lapangan terdapat kebocoran pada beberapa tempat di sistem pembangkit.

\subsection{HASIL ANALISIS EFISIESI EKSERGI}

Efisiensi eksergi dilakukan dengan analisis pada komponen mesin boiler, turbin, dan kondensor dengan analisis dilakukan pada setiap penambahan kondisi pembebanan serta pada tingkatan temperatur lingkungan. Hasil analisis pada Gambar 5 dan Gambar 6 menunjukkan grafik 
efisiensi eksergi unit 1 dan unit 2 PLTU Muara Jawa dengan temperatur lingkungan $25^{\circ} \mathrm{C} ; 27^{\circ} \mathrm{C}$; dan $30^{\circ} \mathrm{C}$ serta pembebanan daya generator $50 \%$; $75 \%$ dan $100 \%$. Efisiensi eksergi pada boiler unit 1 mengalami peningkatan pada setiap penambahan kondisi pembebanan, hal tersebut disebabkan oleh meningkatnya temperatur yang terjadi pada lingkungan sekitar boiler yang menyebabkan energi lingkungan membantu peningkatan efisiensi boiler unit 1 namun pada boiler unit 2 pada setiap penambahan kondisi pembebanan mengalami penurunan yang berbeda dengan boiler unit 1 . Pada boiler unit 2 mengalami laju kerusakan eksergi yang meningkat secara signifikan (dapat dilihat pada Gambar 4) sehingga tingkat efisiensi eksergi pada boiler unit 2 mengalami penurunan. Hasil analisis efisiensi eksergi pada turbin unit 1 dan unit 2 dengan temperatur lingkungan $25^{\circ} \mathrm{C} ; 27^{\circ} \mathrm{C}$; dan $30^{\circ} \mathrm{C}$ relatif mengalami penurunan seiring dengan meningkatnya kondisi pembebanan, hal ini disebabkan karena semakin meningkatnya laju kerusakan eksergi yang terjadi pada turbin unit 1 dan unit 2. Hasil analisis efisiensi eksergi pada kondensor dengan temperatur lingkungan $25^{\circ} \mathrm{C} ; 27^{\circ} \mathrm{C}$; dan $30^{\circ} \mathrm{C}$ dapat dikatakan mengalami penurunan walaupun meningkat pada kondisi pembebanan $75 \%$ dan kembali menurun pada kondisi $100 \%$ kondisi pembebanan pada unit 1 . Berbeda halnya dengan kondensor unit 2 yang relatif menurun, hal tersebut dikarenakan kalor dari dalam sistem kondensor dipindahkan keluar sistem, sehingga terjadi peningkatan laju kerusakan eksergi, atau dapat dikatakan nilai perubahan entropi pada proses kondensor mengalami peningkatan.

\section{Efisiensi Eksergi Unit 1}

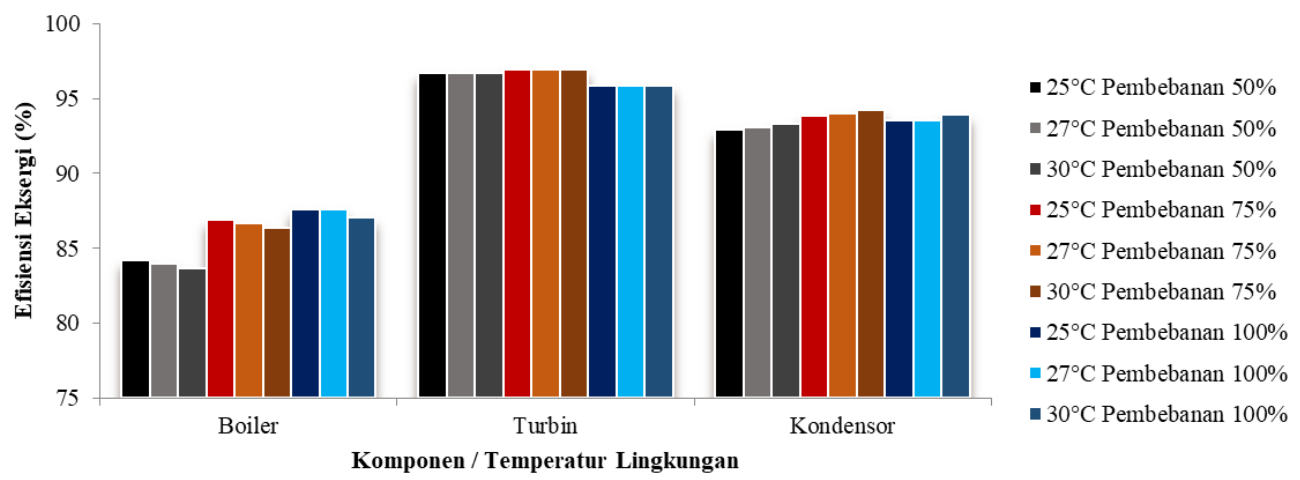

Gambar 5. Hasil Analisis Efisiensi Eksergi Unit 1 pada Temperatur Lingkungan $25^{\circ} \mathrm{C} ; 27^{\circ} \mathrm{C}$; dan $30^{\circ} \mathrm{C}$

\section{Efisiensi Eksergi Unit 2}

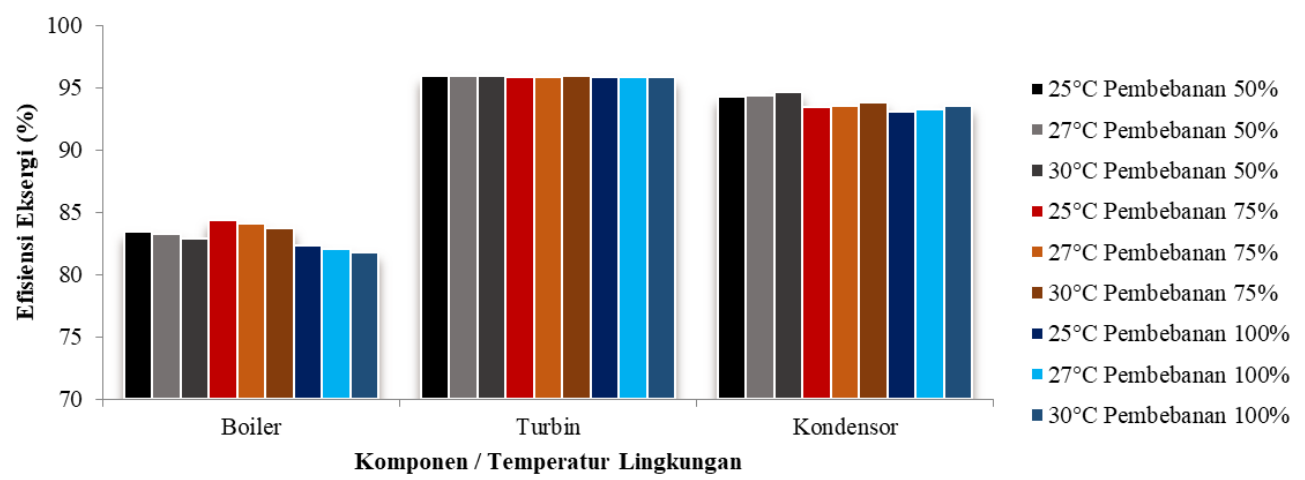

Gambar 6. Hasil Analisis Efisiensi Eksergi Unit 2 pada Temperatur Lingkungan $25^{\circ} \mathrm{C} ; 27^{\circ} \mathrm{C}$; dan $30^{\circ} \mathrm{C}$ 
Gambar 5 dan Gambar 6 menunjukkan hasil analisis grafik efisiensi eksergi pada boiler unit 1 dan unit 2 dengan peningkatan temperatur lingkungan $25^{\circ} \mathrm{C} ; 27^{\circ} \mathrm{C}$; dan $30^{\circ} \mathrm{C}$ mendapatkan hasil yang menurun, hal ini dikarenakan adanya peningkatan laju kerusakan eksergi yang terjadi di boiler yang menyebabkan peningkatan nilai perubahan entropi pada proses boiler sehingga menyebabkan penurunan efisiensi eksergi dari boiler. Pernyataan ini sejalan dengan [9], yang menyatakan bahwa perubahan entropi pada sistem mempengaruhi efisiensi eksergi dari sistem tersebut . Hasil analisis grafik efisiensi eksergi turbin pada unit 1 dan unit 2 dengan peningkatan temperatur lingkungan $25^{\circ} \mathrm{C} ; 27^{\circ} \mathrm{C}$; dan $30^{\circ} \mathrm{C}$ mengalami peningkatan pada kondisi pembebanan $75 \%$ daya generator, hal ini dikarenakan oleh menurunnya laju kerusakan eksergi tertinggi yang terjadi pada turbin dikondisi $75 \%$ daya generator tersebut. Namun demikian, pada kondensor relatif mengalami peningkatan efisiensi eksergi pada setiap peningkatan temperatur lingkungan $25^{\circ} \mathrm{C} ; 27^{\circ} \mathrm{C}$; dan $30^{\circ} \mathrm{C}$, hal ini disebabkan karena laju kerusakan eksergi mengalami penurunan pada setiap kenaikan temperatur lingkungan $25^{\circ} \mathrm{C} ; 27^{\circ} \mathrm{C}$; dan $30^{\circ} \mathrm{C}$.

Analisis efisiensi eksergi pada boiler mengalami peningkatan dibandingkan analisis efisiensi energi. Hal ini dikarenakan pada analisis efisiensi energi hanya dilakukan pada sistem tanpa adanya pengaruh lingkungan yang dapat merugikan sistem maupun menguntungkan. Berbeda dengan analisis efisiensi eksergi yang memperhitungkan kondisi energi di lingkungan sekitar sistem. Walaupun dengan meningkatnya temperatur lingkungan menyebabkan entropi meningkat yang membuat laju kerusakan eksergi meningkat, hal tersebut juga terjadi pada energi yang meningkat, yang membantu terutama pada penambahan jumlah energi pada sistem yang meningkatkan efisiensi eksergi sistem. Dapat disimpulkan bahwa kerja sistem yang melakukan perpindahan kalor pada temperatur lingkungan yang semakin tinggi maka kerja sistem yang melakukan perpindahan kalor akan semakin meningkat sehingga efisiensi ekserginya juga akan semakin meningkat, berbeda dengan kondisi kerja sistem yang melakukan perpindahan kalor pada temperatur lingkungan yang rendah maka kerja sistem yang melakukan perpindahan kalor akan semakin rendah sehingga efisiensi ekserginya juga akan semakin rendah.

\section{KESIMPULAN}

Efisiensi energi tertinggi terjadi pada saat pembebanan $75 \%$ daya generator yang terjadi pada unit 1. Unit 2 mengalami penurunan efisiensi walaupun pada kondisi pembebanan $75 \%$ daya generator efisiensi energi masih yang tertinggi. Laju kerusakan eksergi tertinggi pada unit 1 dan unit 2 terjadi pada kondisi $100 \%$ daya generator dan temperatur lingkungan $30^{\circ} \mathrm{C}$. Efisiensi eksergi tertinggi terjadi pada boiler unit 1 pada kondisi $100 \%$ daya generator dan temperatur lingkungan $25^{\circ} \mathrm{C}, 27^{\circ} \mathrm{C}$, dan $30^{\circ} \mathrm{C}$, Efisiensi eksergi pada turbin dengan kondisi $50 \%$ dan $75 \%$ daya generator dan temperatur lingkungan $25^{\circ} \mathrm{C} ; 27^{\circ} \mathrm{C}$; dan $30^{\circ} \mathrm{C}$. Kondensor dengan kondisi $75 \%$ daya generator dan temperatur lingkungan $30^{\circ} \mathrm{C}$ untuk unit 2 Efisiensi eksergi tertinggi terjadi pada boiler pada kondisi $75 \%$ daya generator dan temperatur lingkungan $25^{\circ} \mathrm{C} ; 27^{\circ} \mathrm{C}$; dan $30^{\circ} \mathrm{C}$. Efisiensi eksergi pada turbin dengan kondisi $50 \%$ daya generator dan temperatur lingkungan $30^{\circ} \mathrm{C}$, dan kondensor dengan kondisi $50 \%$ daya generator dan temperatur lingkungan $25^{\circ} \mathrm{C} ; 27^{\circ} \mathrm{C}$; dan $30^{\circ} \mathrm{C}$. Dari hasil analisis didapati bahwa pembebanan terbaik berada pada saat kondisi $75 \%$ daya generator dan temperatur lingkungan $30^{\circ} \mathrm{C}$. Sehingga dapat dikatakan pada kondisi tersebut pembangkit dalam kondisi optimal. Hasil analisis juga menunjukkan bahwa analisis efisiensi eksergi mendapatkan nilai lebih tinggi dibandingkan analisis efisiensi energi hal ini disebabkan karena analisis energi hanya dilakukan pada sistem tanpa mempertimbangkan faktor lingkungan sistem, sehingga analisis terbaik adalah dengan melakukan analisis eksergi maupun analisis energi agar didapatkan nilai kondisi analisis yang optimal.

\section{UCAPAN TERIMA KASIH}

Penulis mengucapkan terima kasih kepada PT Indo Ridlatama Power yang telah mengizinkan untuk melakukan penelitian ini, kepada Institut Teknologi Kalimantan dan semua pihak yang terlibat dalam penelitian. 


\section{DAFTAR PUSTAKA}

[1] RUPTL PT PLN, "Rencana Usaha Penyediaan Tenaga Listrik PT Perusahaan Listrik Negara (PERSERO) Tahun 2018 S.D. 2027,” 2018.

[2] B. Waluyo, "Proyeksi Penyediaan Energi di Wilayah Lampung Menggunakan Perangkat Lunak Longe-Range Energy Alternatives Planning System (LEAP)," Universitas Lampung, 2013.

[3] E. F. Ansori, "Analisis Termodinamika Pengaruh Operasi Feedwater Heater pada Performa PLTU 3 Bangka Belitung menggunakan Software Cycle Tempo," Institut Teknologi Sepuluh November, 2017.

[4] S. Hariyadi and A. Setiyawan, "Analisa Termodinamika Pengaruh Penurunan Tekanan Vakum pada Kondensor Terhadap Performa Siklus PLTU Menggunakan Software Gate Cycle," J. Tek. Pomits, no. 3, 2014.

[5] R. Phanama, Y. M. Simanjuntak, and M. Ivanto, "Analisis Eksergi Sistem Pembangkit Listrik Tenaga Uap (PLTU) di PT. Indonesia Power Unit Jasa Pembangkitan Sanggau,” J. Mhs. Prodi Tek. Mesin, vol. 1, no. 1, 2019.

[6] A. Karyadi and C. Rangkuti, "Analisa Energi Dan Eksergi Pembangkit Listrik Tenaga Uap,” Semin. Nas. Cendekiawan, 2016, [Online]. Available: http://www.trijurnal.lemlit.trisakti.ac.id/index.php/semnas.

[7] A. Bejan, G. Tsatsaronis, and M. Moran, Thermal Design and Optimization. New York: John Wiley and Sons, 1995.

[8] T. J. Kotas, The Exergy Method of Thermal Plant Analysis. Essex: Elsevier Science, 1985.

[9] A. P. Ismantoro, “Analisis laju Kerusakan Exergy dan Efisiensi Exergy Mesin PLTGU PT. Indonesia Power Unit Pembangkitan Semarang," Universitas Sanata Darma, 2016. 